\title{
Effect of Dietary Amorphophallus sp From East Java on LDL-C Rats (Rattus novergicus Wistar Strain)
}

\author{
Harijati $\mathbf{N}^{1 *}$, Widyarti $\mathbf{S}^{1}$, Azrianingsih $\mathbf{R}^{1}$ \\ ${ }^{1}$ Biology Department, Faculty of Mathematic and Sciences, Brawijaya University, Indonesia
}

\begin{abstract}
One of indication of obesity is high LDL-C . Obesity has serious risk to health, it can cause heart disease and stroke. Effort to lower obesity using drugs have significant side effects such as insomnia, increased blood pressure, dry mouth and so forth. Therefore using natural products that contain glucomannan to reduce obesity and LDL-C is good choise. Glucomannan in the global market derived from Amorphophallus konjac. In this study, we used glucomannan from Amorphophallus endemic East Java to reduce fattened Wistar rats. Amorphophallus that used include Amorphophallus muelleri, A.variabilis (variant: Brongkos 32; Brongkos 5; Wonorejo, Brangsi) and Amorphophallus campanulatus (Var Selopuro). Amorphophallus diet was given to white rats of Wistar strain that previously fattened using a mixture of cholesterol and lard, in addition to PARS (Chicken Feed Race Super) as a basic food. Amorphophallus konjac was used as control. Measurement of LDL-C was conducted in four different time points, namely 1). Prior to dietary cholesterol, 2). 24 days after the dietary cholesterol, 3 ) 11 days after Amorphophallus (+cholesterol) diet, 4). 25 days after Amorphophallus (+cholesterol) diet. The results showed that the diet of A.variabilis potentially lowered blood cholesterol levels for their respective $22.98 \%, 5.85 \%$ and $7.37 \%$ for consecutive variant Brongkos 32; Brongkos 5; Wonorejo. Diet from A.campanulatus and A.konjac had not been able to reduce cholesterol to the end of observation (25 days).
\end{abstract}

Keywords: LDL-C, A.variabilis, A.muelleri, A.campanulatus, A.konjac

\section{Introduction}

LDL-C is bad cholesterol that tends to attach themselves to blood vessels. Cholesterol attachment in the artery to the heart will cause an incrase cardiovascular cardiovascular disease risk. While thr cholesterol presence in the arteries leading to brain will cause the risk of stroke. Therefore, an effort was needed to lower LDL-C content. Glucomannan diet is one of solution to reduce LDL-C level.The glucomannan commercially available in the market was a result of refined the Amorphophallus konjac, known as konjac-glucomannan (KGM) [11]. Amorphophallus konjac had been found in China and Japan. Based on the data available on the official site of Amorphophallus (http://aroid.org), A.konjac had not been found in Indonesia. However other Amophophallus were found in Indonesia, including the East Java. Possibly endemic Amorphophallus in East Java

\footnotetext{
*Corresponding address:

Nunung Harijati

Biology Department, Faculty of Mathematic and

Sciences, Brawijaya University

Jl. Veteran, Malang, JawaTimur. Indonesia 65146

Phone : :62-341-575841

Email : harijati@ub.ac.id
}

contain high glucomannan and had a potential to reduce LDL-C. Therefore, it was necessary to study glucomannan diet mealthat comes from endemic Amorphophallus spp in East Java to reduce of LDL-C.

As a soluble fiber, glucomannan can be used to relieve constipation by decreasing the residence time of fecal material [7]. Glucomanan can also be used to reduce weight [6]. In obese patients, consumption of 1 gram of glucomannan and $250 \mathrm{ml}$ of water one hour before meals, three times per day for 8 weeks resulted lowering $2.5 \mathrm{~kg}$ body weight [14]. Not only in losing weight, Walsh et al. (1984) also showed that obese patients succeeded in reducing total cholesterol significantly. In healthy men, consumption of 3.9 grams of glucomannan for 4 weeks lowered total cholesterol (10\%), LDL cholesterol (7.2\%), triglycerides (23\%) and blood pressure cytosolic $(2.5 \%) \quad[1]$. In Babbon, glucomannan supplementation lowered liver cholesterol [12]. The same result obtained using mice in the laboratory experiments. The mice showed to have a decrease in cholesterol level when feeded with glucomannan diet or combination of glucomanan and chitosan [5]. More over glucomannan (Konjac glucomannan) diet also resulted in improved lipid level and a decreased 
of diabet type 2 fasting blood sugar. Based on this Konjac glucomannan can be used as a suitable supplement for type 2 diabetes [4]. In addition to improving blood lipid profile, glocomanan can also improve glycemic control and cystole blood pressure [13]. And combination of glucomannan and sterol substantially can improve the low-density lipoprotein cholesterol (LDL) as well [15].

\section{Materials and Methods}

Glucomanan source materials were taken from endemic Amorphophallus located in East Java: Amorphophallus campanulatus (from Selopurocalled Selopuro yam), Amorphophallus muelleri (from Madiun-called Madiun yam), Amophophallus variabilis (4 variants: called Brangsi yam, Brongkos 32 yam. Brongkos 4 yam, Wonorejo yam). Amorphophallus konjac (from Fukoaka, Japan) used as a control. All Amorphophallus was made chips, dried $\left(70^{\circ} \mathrm{C}\right.$, 3 days), finely powdered. The glucomannan analyzing was conducted according to Chaerul and Chaerul [2] method.

\section{Fattening Rats}

2.5 months old Wistar strain Rat (Rattus novergicus), acclimatized in the laboratory with standard feeding (150 g flour PARS/ chicken feed super-Confeed, $50 \mathrm{~g}$ wheat flour) as $6 \mathrm{~g} / \mathrm{rat}$ and provided drinking water sufficiently. Fattening occurred after 11 days acclimatization. Fattening is conducted using cholesterol 0.23 $\mathrm{mg} / \mathrm{kg} / \mathrm{BW}$ and lard $4.36 \mathrm{mg} / \mathrm{Kg} / \mathrm{BW}$

\section{Treatment}

The treatments are organized into eight dietary groups of rats:

A*: Without cholesterol (only PARS and wheat flour diet)

B : Cholesterol diet** + A.konjac

C : Cholesterol diet + A.variabilis (var.Brangsi)

$\mathrm{D}$ : Cholesterol diet + A.variabilis (var. Brongkos 32)

E : Cholesterol diet+ A.variabilis (var. Brongkos 5)

$\mathrm{F}$ : Cholesterol diet + A.variabilis(var Wonorejo)

$\mathrm{G}$ : Cholesterol diet + A.muelleri

$\mathrm{H}$ : Cholesterol diet + A.campanulatus (var Selopuro)
Notes

*each group: 5 rats

** $6 \mathrm{~g} / \mathrm{rat}$, after acclimatization (day 12) until day 63.

Cholesterol diet consisting of $150 \mathrm{~g}$ flour PARS /

super chicken feed (Confeed), $50 \mathrm{~g}$ wheat flour, 27,

$93 \mathrm{~g}$ lard, $1.5 \mathrm{~g}$ cholesterol and $0.75 \mathrm{~g}$ of cholic acid

Time-point measurement of blood LDLcholesterol

LDL-cholesterol were measured using blood serum at day 11 (before the cholesterol diet, cholesterol diet start at day 12), 35 (before diet Amorphophallus, the diet begins day 38), 49, and 63.

\section{Diet Amorphophallus sp}

Diet Amorphophallus sp was conducted by direct feeding with dose $60 \mathrm{mg} / \mathrm{kg} /$ body weigh / day. The flour was dissolved in warm water before delivered directly into the rat digestive tract through the esophagus every day from day 38 to day 63.

\section{Fixed parameter}

Body weigh were measured every day; LDL-C are measured at four points time as describe above

\section{RESULTS AND DISCUSSION}

\section{The content of glucomannan.}

The measurement results showed that A.konjat had the highest glucomanan content (Table 1). This result is proof why the A.konjac is always use as a pure glucomannan source. In addition of A.konjac, A. variabilis var. Brongkos 5 (hereafter called Brongkos 5 yam) and Brangsi (hereafter called Brangsi yam) have high glucomanan content as well, followed by A.muelleri. A.campanulatus gave false high result because the extracted filtrates were dominated by starch. And this fact was reinforced by the structure of the filtrate which can not form a gel when mixed with isopropyl alcohol. Forming gel is one of glucomannan characteristic. Based on tuber color, A.variabilis was marketable because buyer prefer flour with white color than other colors. Finally, we concluded that A.variablis as endemic Amorphophallus in East Java is a potential source of glucomannan and to be considered for cultivation. 
Table 1. The measurement results of glucomannan from varies Amorphophallus sp

\begin{tabular}{|l|c|c|c|}
\hline \multicolumn{1}{|c|}{ Amorphophallus } & $\begin{array}{c}\text { Glucomannan content } \\
(\%)\end{array}$ & $\begin{array}{c}\text { texture of extraction } \\
\text { result }\end{array}$ & flesh tuber color \\
\hline A.Konjac & 10.34 & Gel & white \\
\hline A.variabilis (var.Brangsi) & 4.73 & Gel & white \\
\hline A.variabilis (var.Brongkos 32) & 2.97 & Gel & white \\
\hline A.variabilis (var.Brongkos 5) & 5.06 & Gel & white \\
\hline A.variabilis (var.Wonorejo) & 3.19 & Gel & white \\
\hline A.Muelleri & 4.40 & Gel & yellow \\
\hline A.campanulatus (var.Selopuro) & 4.62 dom.starch & No gelling & yellow \\
\hline
\end{tabular}

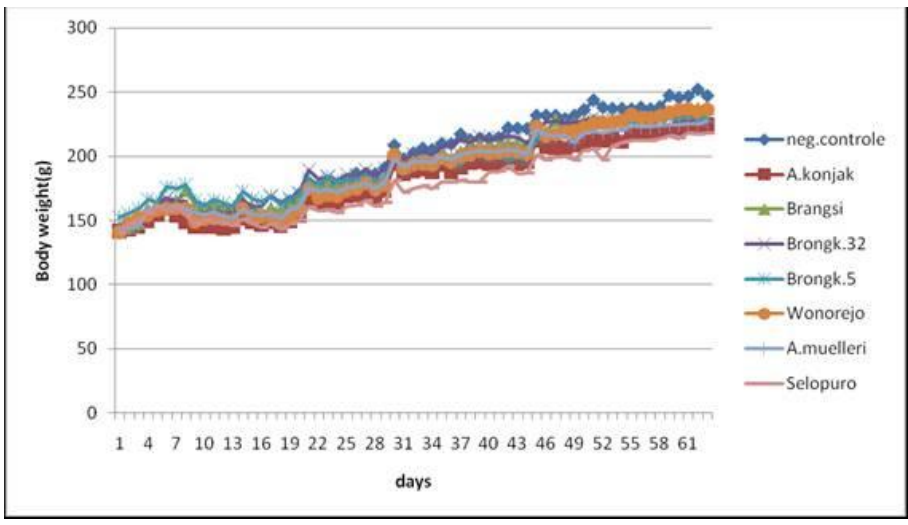

Figure 1. Weight Rats During 63 days of observation. A: control without exposure to dietary cholesterol; B: treatment of A.konjac (+ cholesterol diet); C: treatment of Brangsi yam (+ cholesterol diet); D: treatment of Brongkos 32 yam (+ cholesterol diet); E: Brongkos 5 yam (+ cholesterol diet); F: treatment Wonorejo yam (+ cholesterol diet); G: treatment of $A$. muelleri ( + cholesterol diet); $\mathrm{H}$ : treatment of A.campanulatus (+ cholesterol diet)

\section{Body weight}

The diets effect of mixed feeding (cholesterol, lard and yam flour) on body weight is shown in figure1. Body weight indicator was not as expected. Rat body weight continued to rise since acclimatization until the end of experiment, even after given diets yam flour. Increasing of rat body-weight in both control and treatment indicated that administration of cholesterol and lard did not fatten. The treatment rats were not significantly different from negative controls. Diet 'crude extract' flour yam $60 \mathrm{mg} / \mathrm{kg}$ or $10 \mathrm{mg} / \mathrm{rat}$ could not give the real effect of weight loss. Therefore considered there was another indicator to see the effect of glucomannan that related with obesity. The cholesterol content was proved to have correlation with obesity significantly [8]

\section{Blood cholesterol content}

The result analysis of cholesterol (LDL-C), showed that administration of cholesterol diet for 24 days (day 12-35) led to increased blood cholesterol (from $12 \pm 1.2 \mathrm{mg} / \mathrm{dL}$ to $37.6 \pm 7.7$ $\mathrm{mg} / \mathrm{dL}$ ). Blood cholesterol (LDL-C) in the group without dietary cholesterol did not increase relatively to the range of $12-12.4 \mathrm{mg} /$ dL. This suggested that cholesterol diet has induced a significant increase in LDL-C (Fig.2). Twenty five days after treatment using glucomannan (Counted from from day 38 until 63), gave varies result between Amorphophallus. Diet of glucomannan from $A$. konjac, Brangsi yam, A. mulleri, and Selopuro yam failed to lower blood cholesterol. However glucomannan from Brongkos 32 yam, var Brongkos 5 yam, and Wonorejo yam can lower blood cholesterol rat respectively by $22.98 \%, 5.83 \%$ and $7: 37 \%$. It can be concluded that administration of glucomannan from Brongkos 32 yam, Brongkos 5 yam, and Wonorejo yam gave effect to a decrease in blood cholesterol faster than that of glucomannan from $A$. konjac, Brangsi yam, $A$. mulleri, and selopuro yam (Table 2). In other words A.variabilis potentially lowers cholesterol more than A.konjac, A.muelleri and $A$. campanulatus. And among A.variabilis there was the potential different. When viewed kinds of variants, A.variabilis var Brongkos 32 was most potent than var.Brongkos 5 and var. Wonorejo. However, if the observed days decreased from day 49 to day 63, A.variabilis var Brongkos 5 was most potential. And when viewed overall at the point of measurement day 49 to day 63, except 
controls, all showed a tendency lowering LDL-C. It meant that this study supported previous research that glucomannan had the potential to reduce LDL-C $(1 ; 3 ; 5 ; 15 ; 10)$. Associated with the measurement glucomannan (Table 1), A. konjac should give decline LDL-C greater than others Amorphophallus, because it contained the highest glucomannan. There were two alternatives to address this fact, namely 1).
Extend diet yam, for example 4 weeks more. There was a possibility A.konjac will be greater lowering of LDL-C or remain consistent with the results of the day to 63,2 ). Test expression of genes encodes synthesis glucomannan, namely glucomannan synthase [9]. Possible gene expression of glucomannan synthase from $A$. Konjac is less strong than A.variabilis

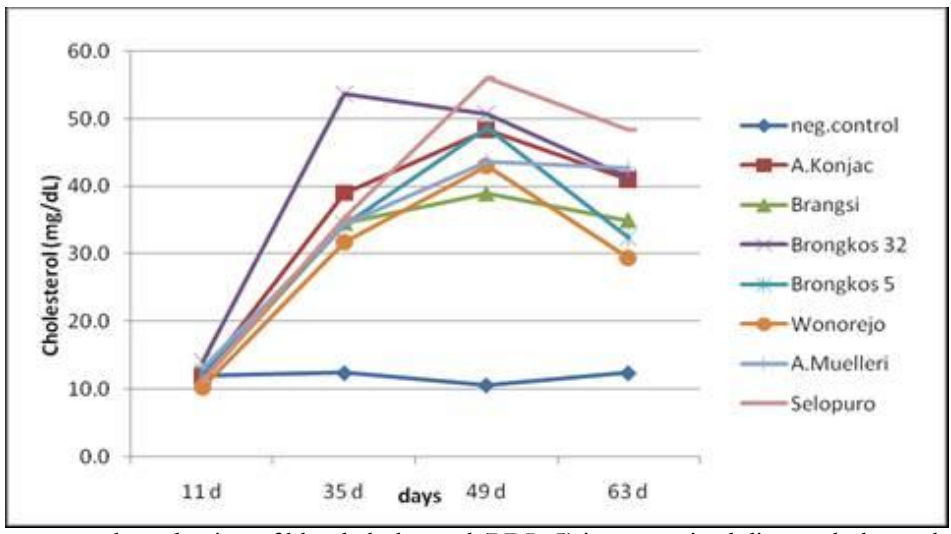

Figure 2. Effect of glucomannan on the reduction of blood cholesterol (LDL-C) in rat received dietary cholesterol. Day 38 starts yam diet (arrows)

Table2. Reduced Percentage blood cholesterol after glucomannan administration from varies Amorphophallus

\begin{tabular}{|c|c|c|c|c|c|}
\hline \multirow{2}{*}{$\begin{array}{l}\text { Treatment Cholesterol and } \\
\text { Glucomana diet }\end{array}$} & \multicolumn{4}{|c|}{ days } & \multirow{2}{*}{ Reduced Percentage blood cholestero } \\
\hline & 11 & $35 *$ & 49 & 63 & \\
\hline Without Cholesterol diet & 12.0 & 12.4 & 10.06 & 12.4 & Constant $0 \%$ \\
\hline A.Konjac & 12.0 & 39.0 & 48.3 & 41.0 & Not appear reduced yet \\
\hline A.variabilis (var.Brangsi) & 11.3 & 34.7 & 39.0 & 35.0 & Not appear reduced yet \\
\hline A.variabilis(var.Brongkos 32) & 14.0 & 53.7 & 50.7 & 41.3 & $\downarrow 22.98 \%$ \\
\hline A.variabilis (var.Brongkos 5) & 12.5 & 34.3 & 48.7 & 32.3 & $\downarrow 5.83 \%$ \\
\hline A.variabilis (var.Wonorejo) & 10.3 & 31.7 & 43.0 & 29.3 & $\downarrow 7.37 \%$ \\
\hline A.Muelleri & 13.0 & 34.3 & 43.7 & 42.7 & Not appear reduced yet \\
\hline A.campanulatus (var.Selopuro) & 11.3 & 35.3 & 56.0 & 48.3 & Not appear reduced yet \\
\hline
\end{tabular}

\section{Conclusion}

The endemic Amorphophallus sp in East Java contain high glucomannan consecutive A.variabilis var Brongkos 5, A.variabilis var Brangsi and A.muelleri. Meanwhile Amorphophallus that greatest lowering of LDL-C for 25 days post yam flour diet is A.variabilis var Brongkos 32.

\section{Acknowledgements}

We thanks to Evit and susiati for experimental help. This work is supported by Directorate General of Higher Education, Ministry of National Education. Grants No: 0114/02304.2/XV/2010

\section{References}

[1] Arvill A and Bodin L.1995. Effect of short-term ingestion of konjac glucomannan on serum cholesterol in healthy men. Am J Clin Nutr. 61 : 585589

[2] Chairul dan Chairul SM. 2006. Isolasi glukomanan dari dua jenis Araceae : Talas (Colocasia esculenta (L.) Schot dan Iles-iles (Amorphophallus campananulatus Blume). Berita Biologi 8(3):171-178

[3] Chearskul S, Sangurai S, Nitiyanant W, Kriengsinyos W, Kooptiwut S, Harindhanavudhi T. 2007. Glycemic and lipid responses to glucomannan in Thais with type 2 diabetes mellitus. J Med Assoc Thai. 90(10):2150-7.

[4] Chen HL, Sheu WH, Tai TS, Liaw YP, and Chen YC.2003. Konjac supplement alleviated hypercholesterolemia and hyperglycemia in type 2 diabetic subjects-a randomized double-blind trial. J Am Coll Nutr. 22:36-42 
[5] Gallaher CM, Munion J, Hesslink Jr R, Wise J and Gal aher DD. 2000. Cholesterol reduction of glucomannan and chitosan is mediated by changes in cholesterol absorption and bile acid and fat excretion in rats . J. Nutr. 130: 2753-2759

[6] Keithley J and Swanson B. 2005. Glucomannan and obesity: a critical review. Altern Ther Health Med. 11(6):30-4

[7] Marzio L, Del Bianco R, Donne MD, Pieramico O, Cuccurullo F.1989. Mouth-to-cecum transit time in patients affected by chronic constipation: effect of glucomannan. Am J Gastroenterol. 8:888-891

[8] Njajou OT, Kanaya AM, Holvoet P, Connelly S, Strotmeyer ES, Harris TB, Cummings SR and Hsueh, WC. 2009, Association between oxidized LDL, obesity and type 2 diabetes in a population-based cohort, the Health, Aging and Body Composition Study. Diabetes/Metabolism Research and Reviews, 25: 733-739. doi: 10.1002/dmrr.1011

[9] Ramsden L and Northcote DH. 1987. Glucomannan synthase from suspension cultures of Pinus sylvestris. Phytochemistry 26(10) : 2679-2683

[10] Sood N, Baker WL, and Coleman CI. 2008. Effect of glucomannan on plasma lipid and glucose concen- trations, body weight, and blood pressure: systematic review andmeta-analysis. Am J Clin Nutr 88:1167-75

[11] Takigami, S., 2000. Konjac mannan. In: Phillips, G.O., Williams, P.A. (Eds.), Handbook of Hydrocolloids. CRC Press, Florida, pp. 413-424.

[12] Venter CS, Vorster HH and Van Ver Nestf DG.1990 Comparison between physiological effects of glucomannan and propionate in baboons fed "Western" diets. American Institute of Nutrition. 90:1046-1053

[13] Vuksan V, Jenkins DJA, Spadafora P, Sievenpiper JI, Owen R, Vidgen E, Brighenti F, Walsh DE, Yaghoubian V and Behforooz A. 1984. Effect of glucomannan on obese patients: a clinical study. Int J Obes. 8: 289-293

[14] Walsh DE, Yaghoubian V and Behforooz A. 1984. Effect of glucomannan on obese patients: a clinical study. Int J Obes. 8: 289-293

[15] Yoshida M, Vanstone CA, Parsons WD, Zawistowski $J$ and Jones PJH. 2006. Effect of plant sterols and glucomannan on lipids in individuals with and without type II diabetes. European Journal of Clinical Nutrition 60:529-537 